\section{应对气候变化的 \\ 沿海社区与生态系统弹性设计 \\ THE DESIGN OF RESILIENT COASTAL COMMUNITIES AND ECOSYSTEMS RESPONDING TO CLIMATE CHANGES}

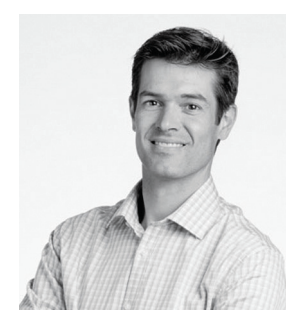

杰弗里 ·卡尼

路易斯安那州立大学沿海地 区可持续性研究所负责人、 建筑学院副教授

\section{Jeffery CARNEY}

Director of Coastal

Sustainability Studio and

Associate Professor in the

School of Architecture,

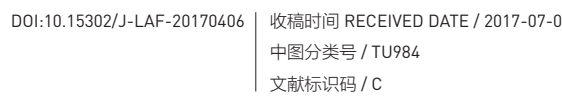

摘要

近年来，风暴、土地流失、海平面上升等问题频发、沿海地区 面临着日益严峻的挑战。路易斯安那州立大学沿海地区可持续性研 究所 (CSS) 自2009年成立以来便致力于通过创新策略提升沿海 社区与生态系统的弹性。本次采访聚焦于CSS的团队建设方式、跨 学科协作, 以及沿海区域大尺度规划设计策略等方面。CSS负责 人杰弗里. 卡尼提出, 气候变化已成为沿海社区规划设计中的重要 考虑因素, 其影响甚至涵盖内陆地区, 因而迫切需要正视这一全球 性问题。卡尼认为，景观设计师的基本职责就是探索如何将复杂的 生态系统融入人类环境之中, 唯有运用系统性思维以及促进各方协 作，才能实现更加富有成效且更具责任感的设计和发展建设。 关键词

沿海地区可持续性研究所; 海岸修复; 沿海生态系统保护; 气候变 化; 协作

\section{ABSTRACT}

In recent years, challenges of storms, land loss and sea level rise are getting more and more serious in the coastal areas. Since its founding in 2009, the Coastal Sustainability Studio (CSS) of Louisiana State University has been trying to use innovative approaches to foster resilient coastal communities and ecosystems. This interview focuses on CSS's way of building teams, transdisciplinary collaboration, and their practices on large-scale planning in coastal areas, etc. As is stated by Jeffery Carney, director of CSS, climate change is increasingly recognized as a huge factor in coastal community design and is affecting inland regions as well, which has become a global issue to be seriously concerned. Carney also suggests that it is the duty of landscape architects to put the complexities of the ecosystem into a human context. Only with the application of systems thinking and with collaboration with a diverse team, can we realize design and development in productive and responsible ways.

\section{KEY WORDS}

Coastal Sustainability Studio; Coastal Restoration; Coastal Ecosystem Preservation; Climate Changes; Collaboration

整理 王颖

译 张健 王颖

EDITED BY Ying WANG

TRANSLATED BY Angus ZHANG Ying WANG 


\section{沿海地区可持续性研究所}

美国路易斯安那州立大学沿海地区可持 续性研究所 ( CSS ) 成立于 2009 年, 聚集了科 学家、工程师和设计师等来自多个领域的专 业人士，共同针对风暴、沿海土地流失和气 候变化等问题进行深人研究。通过在跨学科 的设计、研究、社区参与及教育等方面的创 新性举措, $\operatorname{CSS}$ 致力于设计并提升沿海社区与 生态系统的弹性。CSS所从事的实验性设计为 重要政策的制定提供了依据，有助于实现更 加可持续的土地利用规划、保护与教育。

在负责人杰弗里・卡尼的带领下，CSS参 与了众多实践项目，包括路易斯安那州弹性 提升计划、与Moffat \& Nichol事务所及West 8事 务所合作的密西西比河三角洲 “河流改道” 设计竞赛获胜项目“弹性三角洲”，以及新 近荣获由美国国家科学院和罗伯特・伍德 - 约 翰逊基金会资助的 “从沿海到内陆——应对 区域气候变化的多尺度策略”项目

C S S团队中包括工程师、设计师等各领 域人士，他们共同就地面沉降、海岸修复、 洪水防控及经济发展等方面的问题进行深入 研究。这种跨学科团队如何进行协作和 协调?

杰弗里・卡尼（以下简称卡尼）：这 种跨学科的协作过程每一次都有所差异，这 也为我们的工作增添了不少趣味。在成立之 初, CSS便预期能够参与不拘泥于某一学科范 畴的实践，我们聚焦于那些仅靠某一单一部 门或专业难以完成的项目。目前, 我们正致 力于大尺度区域的适应性规划、促成政府官 员参与社区弹性修复工作、引领数字通讯和 展览设计，以及设立跨学科课程等工作。这 些不同类型的项目对所运用的技能和方法有 着不同的要求。我认为, 相较于通过特定架 构的团队来应对问题，依据所需解决的问题 来组建团队更能体现CSS所依托的大学背景的 价值所在。CSS真正实现了不同学科之间的交 叉与融合。

当然, 我们在开展项目和组建团队时,

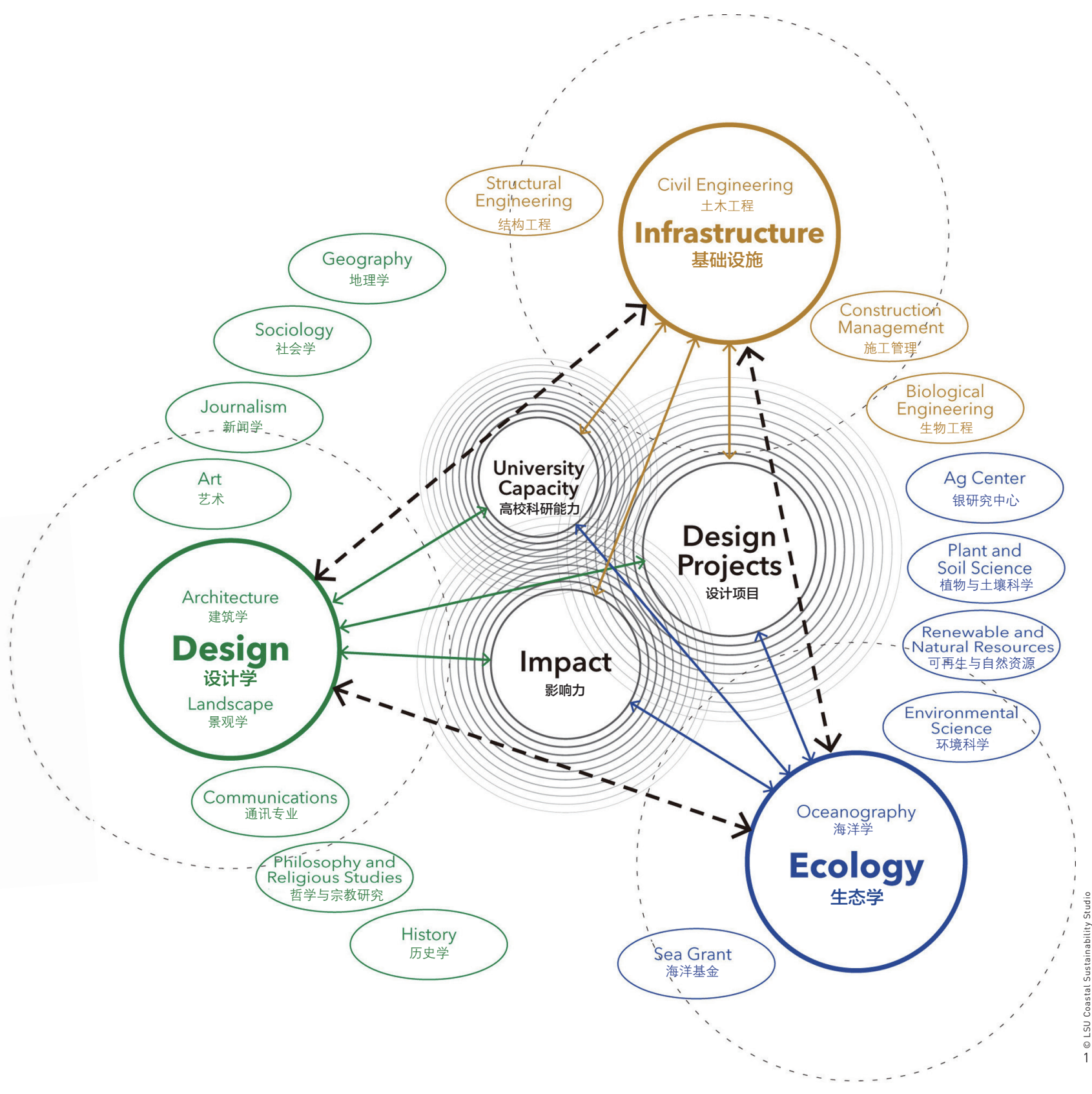
CSS聚集了科学家、工 1. At CSS, scientists, 沿, 就安居、没 每修复、防洪和经济发 等方面的问题进行深 入探究和响应。 2. CSS 实践中的社区参与 engineers, and tosether to intensively the to intensively study and respond to issues of settlement, coastal restoration, flood protection, and the economy.
2. Community engagement in CSS's practices

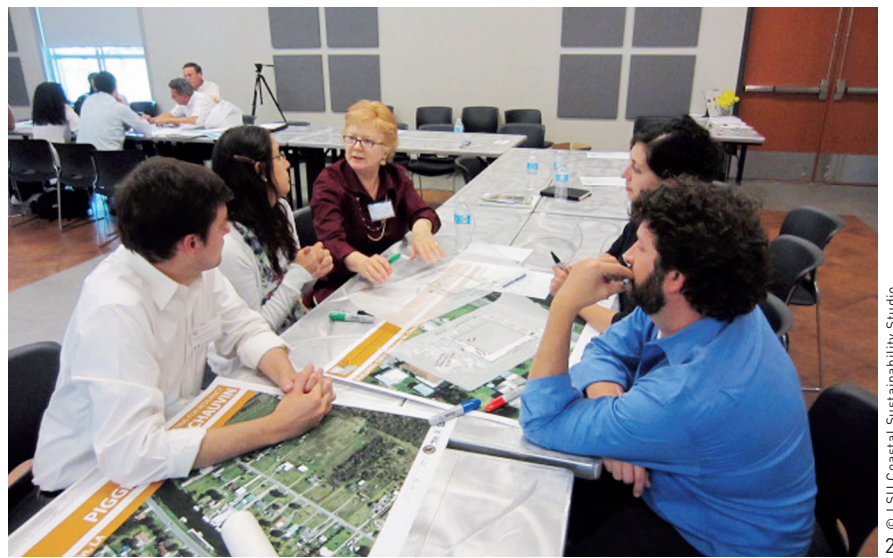




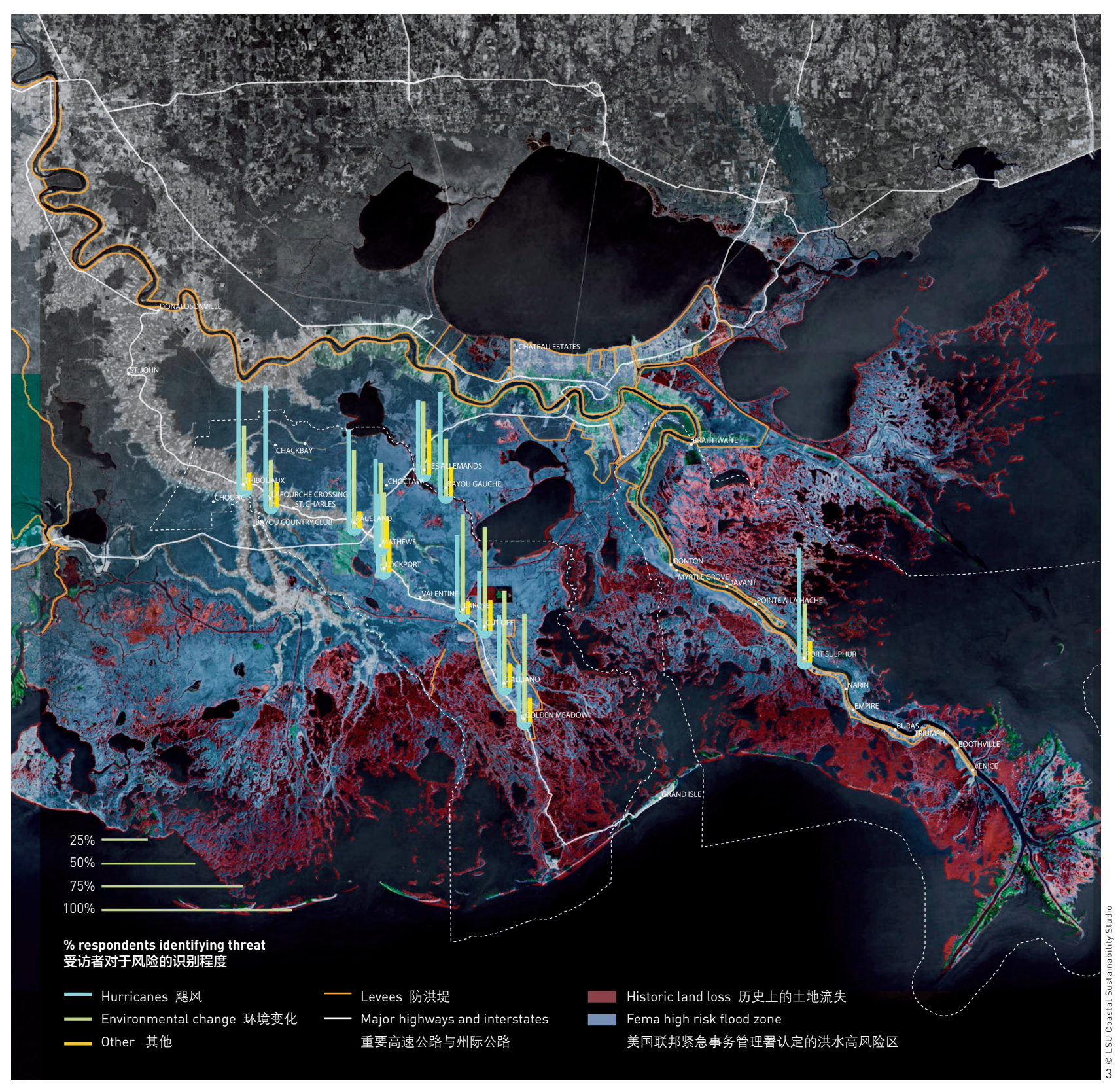

并非每一次都要从零开始。多年来, 由路易 斯安那州立大学院系教师组成的 CSS 核心领 导团队，已经形成了稳定的工作关系，例 如, CSS执行委员会负责招募新成员并对其 在团队中的角色进行定位。我们的工作坚持 以 “设计” 为核心, 并围绕建造过程开展项 目, 力争解决或至少明确当前的问题。作为 设计师, 我们很享受这种时常错综复杂的设 计过程, 在某些情况下, 这种过程着实能够 帮助我们重新定义所面临的问题。这种对解
决方案的反复推敲过程, 与解决方案本身同 样重要。

C S S 建立的初衷即从实验角度出发, 探 索能够降低社会、经济和自然资源所面临风 险的创新策略。CSS 主要通过何种方法来实 现这些策略?

卡尼：风险是一个令人难以环磨的概 念。我们总认为我们知道什么是风险, 但是 
深究其里, 便会发现每个人对风险的定义都 千差万别。以密西西比河洪水造成的风险为 例：沿河社区居民对其的恐慌在于它可能淹 没城市；进行恢复工作的团体却将其视作陆 地形成的重要过程; 而渔民则抱怨它改变了 沼泽的盐度。不同的利益团体在审视问题的 时候往往只狭险地顾及自身的利益。长此以 往, 人们将不断陷人僵局, 以致各方行动受 限, 且无人能够真正获益。

CSS试图运用系统性思维来探索能够克 服或缓解上述矛盾的方案。此前举办的 “河 流改道” 竞赛便对密西西比河的管理提出了 挑战, 该竞赛旨在重新设计更加可持续的密 西西比河下游三角洲。来自世界各地的参赛 团队, 一同为改造密西西比这一美国最丰富 的自然资源提出各自创意性的设计方案。CSS 凭借出色的发挥, 协同其他事务所赢得了竞 赛。获胜方案 “弹性三角洲” 并不以解决某 一特定群体的问题为目标, 而是力图找到一 种使河流重新融人人们生活, 并为所有群体 带来裨益的途径。我们认识到, 沉积物的转 移本身并无利弊之分。长久以来, 河流与沼 泽之间的紧密联系促进了生态系统的健康发 展, 继而带来了良好的社会效益。我们的研 究表明, 在汛期, 河流改道所形成的水流与 沉积物的脉冲式释放, 将有助于缓解防护堤 坝的压力, 形成陆地, 且不会对渔业产生 不利影响。如此一来, 根据洪水的发生周 期, 我们将建立一套能造福于所有群体的 管理方法。

在旧金山SOM事务所工作的经历帮助您 在可持续性大尺度规划、城市设计和建筑设 计等方面积累了丰富的经验。在您看来, 与 城市设计及其他滨水区的设计相比, 沿海地 区的可持续性设计具有怎样的独特之处?

卡尼: 在搬到路易斯安那州之前, 我在 SOM事务所工作了一些年头, 这于我是一段 非常重要的经历。我在那里深刻认识到了大 型城市项目的复杂性, 那种大尺度、大视野 的设计也影响了我在CSS处理项目的方式。尽 管城市尺度的建筑设计与区域尺度的环境和
社区规划之间存在明显的差异，但在这些 项目中, 设计师所扮演的角色有许多共通 之处。

在SOM事务所时, 我曾参与了旧金山帕 克默塞德社区的可持续再开发项目。该项目 计划增加数百座新建筑, 使社区所能承载的 人口变为之前的三倍, 即由约 8000 人增至 24000 人。同时, 市政府要求我们减少雨水 径流, 保持既有用电供给, 并避免对交通造 成影响。这意味着我们需要在结构工程师、 交通工程师、历史学家、水文学家、景观设 计师、建筑师以及其他众多学科的从业人员 之间进行协调。作为该项目的设计师, 与其 说我们是一群全能的设计者, 倒不如说我们 更多地承担了统筹者的角色。我从这一项目

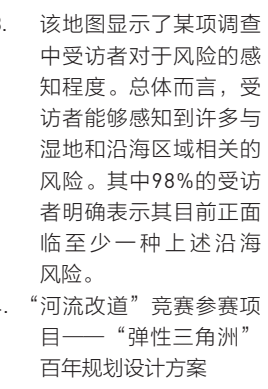

3. The map focuses on perceptions of risk. In general, respondents identified a range of threats to wetlands and coastal conditions confirmed that they are confirmed that they are currently facing at least one identified coastal threats.

4. The 100-year Plan for the "Giving Delta" Entry to the Changing Course Competition.

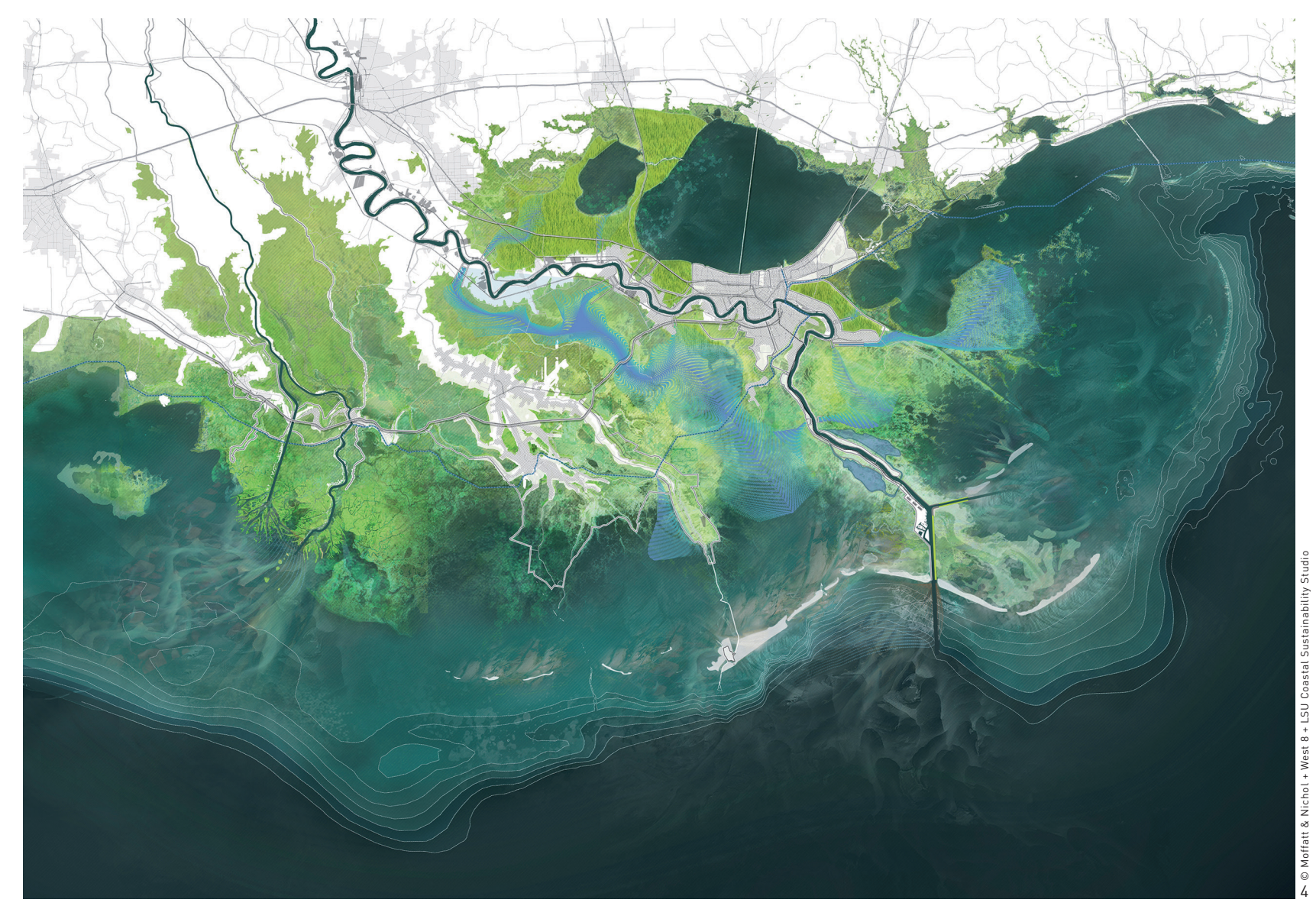


中收获了两点心得：1）设计师应当广泛涉猎 各个领域, 2 ) 设计师要擅长讲故事, 以更 加贴近人们的生活。该项目的成功, 不仅 依赖于我们不断鼓励顾问团队进行深人探 索, 还有赖于我们对这些探索的成果进行综 合, 最终解决了委托方与社区所提出的问题。

正是由于拥有了这些宝贵的经历，我在 $\operatorname{CSS}$ 面对类似的挑战时变得更加自信一一尽管 项目尺度远超之前。在这里, 我们所从事的 是比社区尺度更大的城镇或整个地区的规划 工作，但其中的一些挑战与机遇仍然是相 通的。作为建筑师、景观设计师和城市设 计师, 我们需要协调和综合各方的工作,
并最终以恰当的方式向委托方或公众传达 方案意图。

\section{与内陆地区的设计实践相比, 气候变 化是否是沿海地区设计中需要优先考虑的} 因素?

卡尼：我认为在沿海地区的设计中， 气候变化因素的重要性已不言而喻。世界上 许多地区正面临着海平面的加速上升, 而这 也会相应地改变当地的沿海景观。此外, 我 们发现气候变化甚至对内陆地区也存在影 响。2016年夏天, 在距离海岸2小时车程的
5. 动态景观中的固定系统有 助于我们了解景观在应对 风险时的作用。

5. A fixed system in a dynamic landscape to expand hay we through the lens of through the insurance.

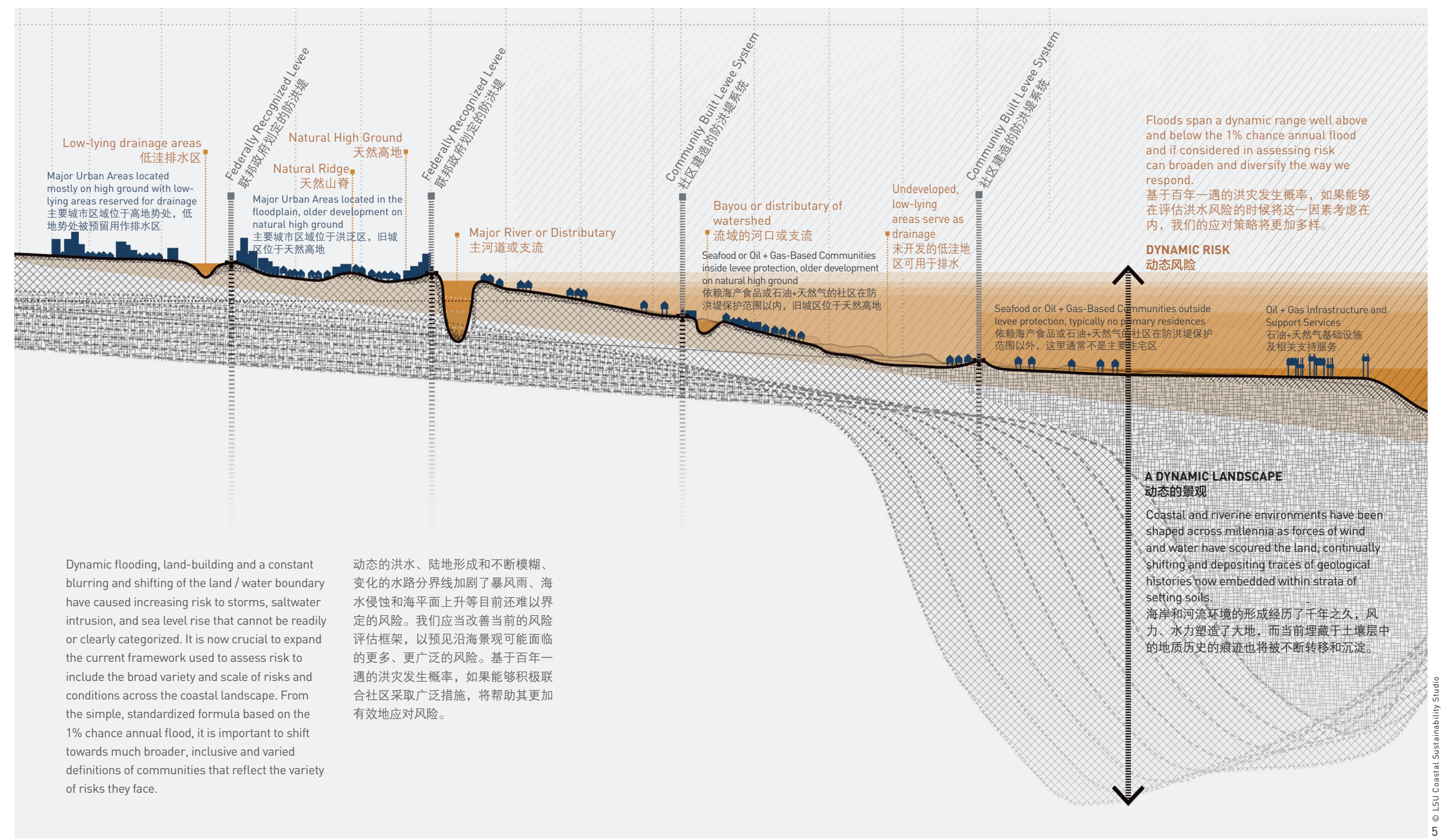


巴吞鲁日市, 短短三天内的降雨量就达到了 $787 \mathrm{~mm}$ 。这是一起千年一遇的强降雨事件, 但令人难以置信的是，这在一年之内已是第 二次发生! 不同于天气系统中被美国国家气 象局命名的风暴, 这种不断增长的一般性降 水通常不会被具体界定, 但近期的研究已表 明，其危险性并不亚于前者。

近期, CSS启动了一个最新项目——从 沿海到内陆”。我们汇集了学术界和专业领 域的不同人士, 试图进一步探究内陆-沿海环 境条件及其脆弱性，探索如何提升社区健康 与福祉, 以及如何实施最优的设计与规划, 以降低风险、提高社区的适应能力。当地的 专业建筑师、工程师、景观设计师、规划 师、决策者及社区成员等，将共同推动项目 研究结果在具体实践中的应用。具体而言, 项目团队期望为遭受洪水重创的大巴吞鲁日 地区找到应对此类灾难性事件的更具弹性的 方法。此外，该项目中所形成的框架，今后 也将适用于墨西哥湾海岸及其他地区。

人类的生产与生活对沿海生态系统产生 了巨大的影响。在CSS的实践中, 如何协调 人类活动与沿海生态系统保护? 公共宣传和 教育在这方面发挥着怎样的作用?

卡尼：景观设计师的基本职责之一就是 探索如何将复杂的生态系统融人人类环境之 中。我们的首要任务是满足人类的需求。正 如我们 “修复” 生态系统并非为其本身，而 是为了方便人们使用、促进人们的健康，并 为其带来愉悦的体验。工程师和沿海相关领 域的科研人员逐渐认识到并承认他们所采用 的方案往往忽略了人类自身的需求。这带来 的结果是, 世界上最优秀的自然修复方案往 往被束之高阁，因为人们无法理解或不能充 分认识其价值。

谈及CSS在公共宣传和教育方面所做的积 极尝试, 河流研究中心 (CRS) 的展览设计项 目是其中一个重要代表。CRS的成立是海岸保 护和修复管理局（CPRA）长期努力的成果。 作为一个州级政府机构, CPRA负责制定、阐 明和执行全面的修复和保护计划，以减少由
䢐风和风暴潮引发的洪水; 修复路易斯安那 州丰富的自然资源；形成陆地以保护国家关 键能源基础设施; 以及保护路易斯安那州海 岸，造福子孙后代。为更好地向公众普及与 海岸修复和保护相关的复杂科学知识, CSS受 CPRA委托, 设计了主题为 “移动的地基” 的 展览（其中截取一个大型实际河流模型的一 部分进行展示), 以协助其明确项目愿景, 阐述项目内容, 并推动开展示范项目。

这一展览计划于 2017 年秋季对外开放， CRS的重要性不仅体现在其作为科研机构所具 有的科学价值，更在于其为复杂的海岸和河 流研究、海岸修复及海岸保护工作所作出的 传播贡献。

C S S目前的实践主要侧重于解决路易斯 安那州沿海地区所面临的复杂问题。在您看 来, CS S的经验对全球沿海问题是否也具有 启发性?

卡尼：冊庸置疑！首先，我由衷地相 信, 当设计师能够与众多团队开展成熟合作 时, 其在世界各地的项目中将发挥更大的能 动作用一一这就是为什么 CSS 几乎将跨学科 的协作视作所有工作的核心。密西西比河三 角洲平原所面临的挑战, 是当今全球许多三 角洲所共同面临的。世界上约有 5 亿人口居住 在三角洲地区，在海平面上升的同时，这些 地区却在不断下沉。无论位于何处，这些三 角洲的发展都极大依赖于自然资源的开采, 且随着人口的不断增加, 贫富差异会日益加 大。除三角洲地区外, 沿海地区和内陆地区 当前所面临的境况一如密西西比河三角洲近 30 年的遭遇。如果说南路易斯安那州是为我 们提供预警的 “煤矿中的金丝雀” ，那么 县风桑迪则是对全世界的一次警示——威 胁并非仅仅存在于三角洲, 海岸及邻近的 内陆地区也面临着风险。因此, 要实现富 有成效且更具责任感的设计和发展建设, 并在这些复杂而充满活力的环境中生活与 工作, 就必须与更多具备广泛知识的各界 人士通力协作。这也正是我们在CSS不断努力 的方向。LAF 
Multiple Lines of Defense Strategy

多防线防御策略

The Multiple Lines of Defense Strategy is an approach for reducing flood risks to

Louisiana's coastal communities that combines restoration and conservation of natural

features found in the coastal landscape with traditional engineered protection features

(a)

“多防线防御策略” 可有效减少路易斯安那州沿海地区的洪水风险, 既修复了沿海景

观，也对邻近城镇中传统的人工防御设施进行了保护。

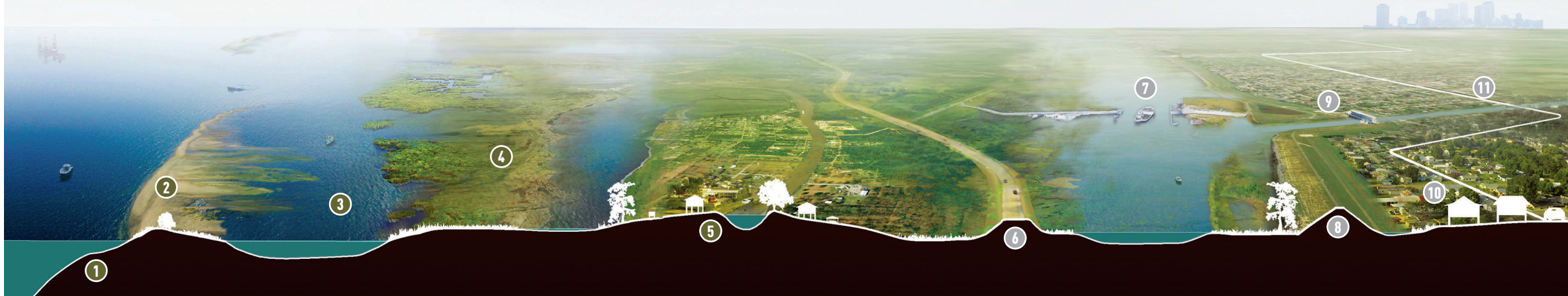

1. Shelf 陆棚

1. shallow shelf can reduce the energy and height of storm induced waves before they reach the coastline.

即从海洋深处到海岸之间的过渡区域。浅水陆棚可在由暴风雨造成的 海浪到达海岸之前, 降低其强度与浪高。

2. Barrier Island 堰洲岛

ong, narrow islands found nearby and parallel to the mainland coast, barrier islands can significantly reduce wave height and help decrease the amount of storm surge that reaches the mainland.

即邻近、平行于大陆海岸的狭长岛屿。堰洲岛可有效降低海浪的高 度, 帮助减少着陆风暴潮的次数

3. Sound 海峡

Large shallow water bodies such as sounds or bays can reduce the nergy of storm surge.

诸如海峡、海湾等大型浅水水域可降低风暴潮的强度。

4. Land Bridge 陆桥

Relatively continuous areas of marsh or swamp, land bridges help reduce the movement of storm surge further inland.

即相对连续的湿地区域。陆桥可帮助减少向内陆移动的风暴潮。

5. Natural Ridge 天然堤岸

The remnants of the natural levees of abandoned rivers and bayous or beach ridges, natural ridges sit higher than much of the surrounding landscape, impeding overland flow of water and helping reduce storm

即废弃河流、海湾或海滩脊所形成的天然堤岸。天然堤岸通常高于周 边的景观，因而可以阻挡地表径流，减少了风暴潮的发生。
6. Highway Foundation 高速公路地基

Foil foundations such as for highways, railroads, or spoi 济

高速公路、铁道、废石堆等人造地基可降低风暴潮的危害。

7. Flood Gates 防洪闸门

Closed during a flood, these structures reduce flood tides from moving up navigation channels

当洪水来临时, 闸门将关闭, 可有效削弱因航道水位上涨而造成的 洪峰。

8. Levees 防洪堤

Constructed levees prevent high water from reaching urban areas.

人造防洪堤可阻挡海水进入城市区域

9. Water Management Infrastructure 水资源管理其础设

Historically, keeping water out of the urban areas behind levees has relied on pumps and canals. New alternatives to reduce flooding include: bioswales, canals, water harvesting mechanisms, pervious paving, tree plantings, rain gardens and more.

水救和运河是用于阻挡漫过防波堤的海水进入城市区域的传统途径。 而新型的可降低洪水风险的举措包括: 生态湿地、集水装置、渗透性 铺装、植树、雨水花园等。

10. Elevated Buildings 高架建筑

Despite all the other lines of defense, there is potential for an overwhelming storm that could flood populated areas, even behind the levee protection. This is the final line of defense for people' $s$ homes and other infrastructure.

即使拥有了上述各种防线，来势凶猛的风暴仍有可能侵袭人口密集的 区域，甚至连防洪堤都难以发挥作用。挑高的建筑是保卫人们居所和 其他基础设施的最后一道防线。

11. Evacuation Routes 疏散通道

These routes are selected to move large numbers of people to safer areas when there is an approaching storm.

这些通道可在暴风雨来临时, 将大量人群疏散至安全地带。 


\section{Introduction of the Coastal Sustainability Studio}

The Louisiana State University (LSU) Coastal Sustainability Studio (CSS) was established in 2009 to help scientists, engineers, and designers come together to intensively study and respond to the challenges from storms, coastal land loss, and climate change. Through transdisciplinary design, research, community engagement, and education, the CSS uses innovative approaches to design and foster resilient coastal communities and ecosystems. The results of this design experimentation provide a sound basis for major policy decisions for adaptation through more sustainable land-use planning, protection, and education.

Jeffrey Carney, as Director of CSS, has led numerous projects with the CSS including the Louisiana Resiliency Assistance Program, the winning "Giving Delta" design as part of the Moffat $\&$ Nichol, West 8, LSU-CSS team for the Changing Course Competition, to the recently awarded grant "Inland from the Coast: A Multi-Scalar Approach to Regional Climate Change Responses" funded through the National Academies of Sciences and the Robert Wood Johnson Foundation.

\section{We know that at Coastal} Sustainability Studio (CSS), engineers and designers come together to intensively study and respond to issues of settlement, coastal restoration, flood protection, and the economy. We would like to learn how these interdisciplinary teams collaborate and coordinate?

\section{Jeffery CARNEY (CARNEY}

hereafter): The process is different every single time, which keeps things interesting. From its beginning, the CSS was organized to take on projects that fell outside the typical domain of any one discipline. We wanted the projects that no one else in an individual department or professional practice could do. We have worked on long-range regional adaptation planning projects, engaged elected officials around issues of resilience, led data communication and exhibition designs, and efforts to build multi-disciplinary curriculum. Each of these project types have required different skills and approaches. The ability to build teams around problems, instead of responding to problems based on the capacity of a pre-formed team, is a capability that I think is unique to a university setting. We have access to a cross section of so many different disciplines.

However, in taking on projects and forming teams, we do not start from scratch each time. Over the years we have developed strong working relationships among faculty that form the core group of the CSS leadership team. The CSS executive committee is responsible for bringing in new people and getting them oriented. Our process is decidedly "design" focused and gears projects around building process for solving (or at least addressing) current problems. As designers, we enjoy this often messy process. Sometimes in fact, the process will re-define the problem. The iterative search for solutions defines our process as much as the solutions themselves.

CSS was conceived as a laboratory to develop innovative strategies that reduce risk to social, economic, and natural resources. What approaches do these strategies employ with?

CARNEY: Risk is a tricky concept. We think it is easy to define but when you dig in a little below the surface you 


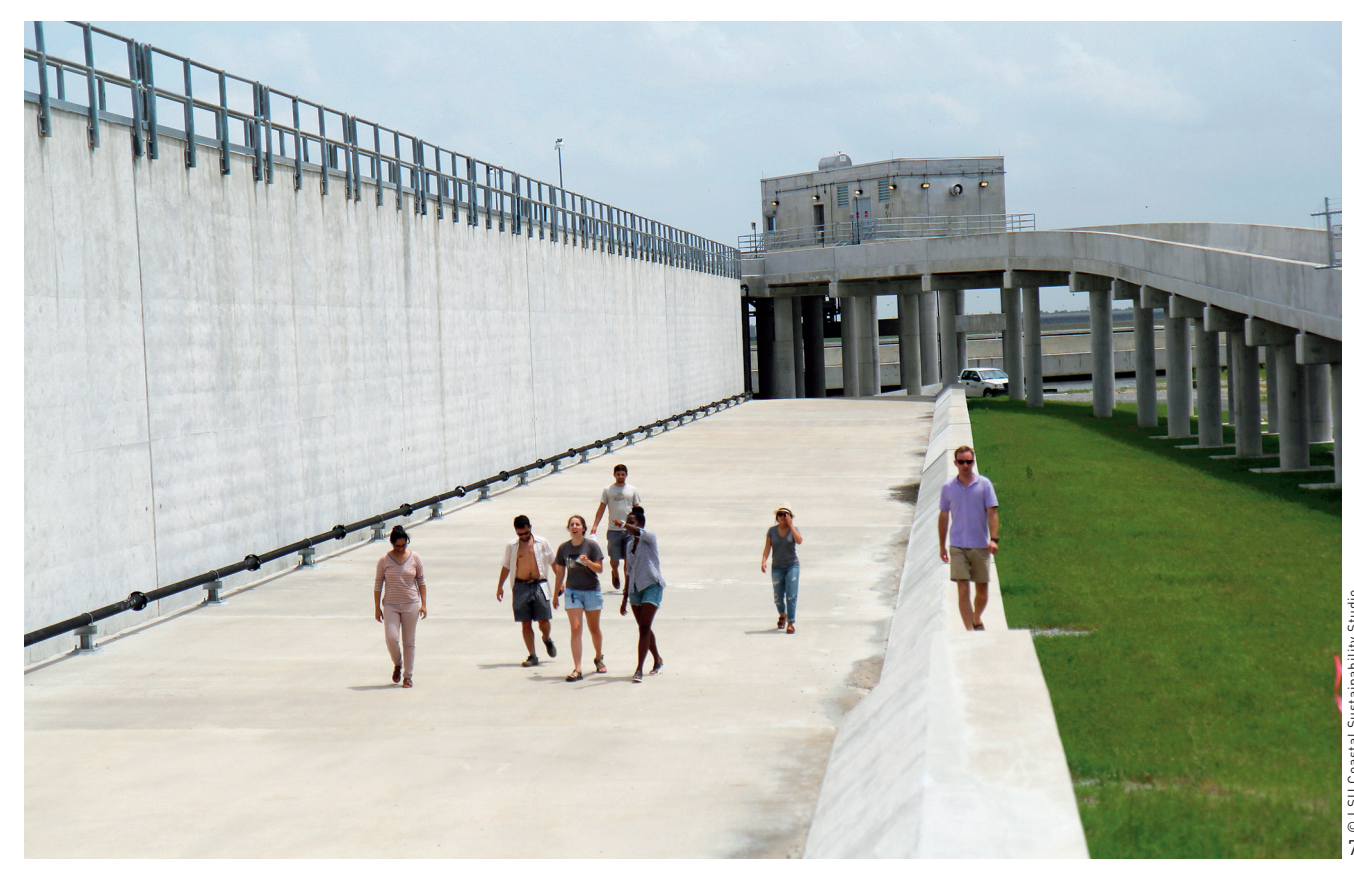

soon realize that everyone defines their risk differently. Take for instance the risk posed by flooding of the Mississippi River. Communities along the river fear flooding because it could inundate their cities; the restoration community sees it as an essential component of land building; fishermen dislike it because it changes the salinity of the marsh. Each interest group sees the problem through their own narrowly defined interests. Unfortunately, this has led to a stalemate, where in the end actions are limited and nobody wins.

The CSS tries to apply systems thinking to such problems to see if solutions might exist that can overcome or at least work around such conflicts. The management of the Mississippi River was the central challenge of the Changing Course Competition, a design competition to reimagine a more sustainable Lower Mississippi River Delta. Teams came together from around the world to create innovative visions for one of America's greatest natural resources, presenting ideas which would change the course of the Lower Mississippi River. CSS was a major contributor on a winning team for the competition. The winning "Giving Delta" proposal was not based on solving the problem of any one constituency but by finding a way to re-engage the river to provide benefit to all groups. Sediment diversions are not inherently good or bad. The connection of the river to the marsh historically has provided significant benefits to the ecosystem which in turn had social benefit. Our research showed that a combination of pulsed releases of water and sediment through diversions when the river was at flood stage would release pressure on protection levees, build land, and not cause harm to fisheries. In this case, the historic cycles of flooding inspired a management regime that would provide benefit to all interest groups.

We also learned that you have significant experience in sustainable large-scale planning, urban design and architectural design from projects you were engaged in while working at Skidmore, Owings, and Merrill (SOM) in San Francisco. We are wondering what the distinctiveness of coastal sustainability design is, compared with the design on urban realm and other waterfront morphologies.

CARNEY: Before moving to Louisiana, I spent a few years working for SOM in San Francisco. This was a tremendous experience where I was fully immersed in the complexities of big urban projects. This scale and scope of design influenced the way I have approached projects in the CSS. Urban scale architecture, and regional scale environmental and community planning are clearly very different. However, there is much in common between the roles of the designer across these scales.

While at SOM, I worked on the sustainable redevelopment of the Parkmerced neighborhood in San Francisco. This project proposed 
tripling the density of a community of roughly 8,000 people to 24,000 with the insertion of hundreds of new buildings.

At the same time, we were required by the city government to reduce the stormwater runoff, maintain the same demand on the energy grid, and make no adverse impact on traffic. This challenge required the coordination of countless disciplines from structural engineers to traffic engineers, historians, hydrologists, landscape architects, architects, and others. As project designers, we operated more as conductor than allencompassing design authors. I learned two lessons - designers need to know a little bit about a lot of things and we also need to be good at telling stories that can reach people. Success in this project relied upon our ability not only to encourage deep exploration by the range of consultants, but also to synthesize the results into a coherent whole that solved the problems put forth by the client and community.

In Louisiana, these experiences prepared me for a similar challenge, albeit at a far larger scale. The neighborhood in this case has been replaced by the town or entire region, but many of the same challenges and opportunities persist. There is a role for architects, landscape architects, and urban designers to coordinate and synthesize the work of a broad range of actors and, in the end, to communicate solutions to a client or the public in a way that is relatable.

Compared with the design practice on inland areas, is climate change a primary factor which should be given absolute priority in the design on coastal areas?

CARNEY: I think that climate change is and will be increasingly recognized as a huge factor in coastal community design. Sea level rise is accelerating in many parts of the world and will correspondingly change the landscape of those impacted in coastal areas. Additionally, we are finding that climate change is affecting inland regions as well. Last summer in Baton Rouge -2 hours from the coast - we had 31 inches of rain in just three days. This tremendous event was considered a one in 1,000-year event. However, it was the second 1,000-year event for 2016 ! Increased general precipitation is not as clearly defined as "named storms" are for other types of weather systems - a practice used by the United States National Weather Service — but recently it has proved just as dangerous.

A new project we have just started in the CSS is called "Inland from the Coast." We are bringing together people from across the academic and professional worlds to improve understanding of inland-coastal
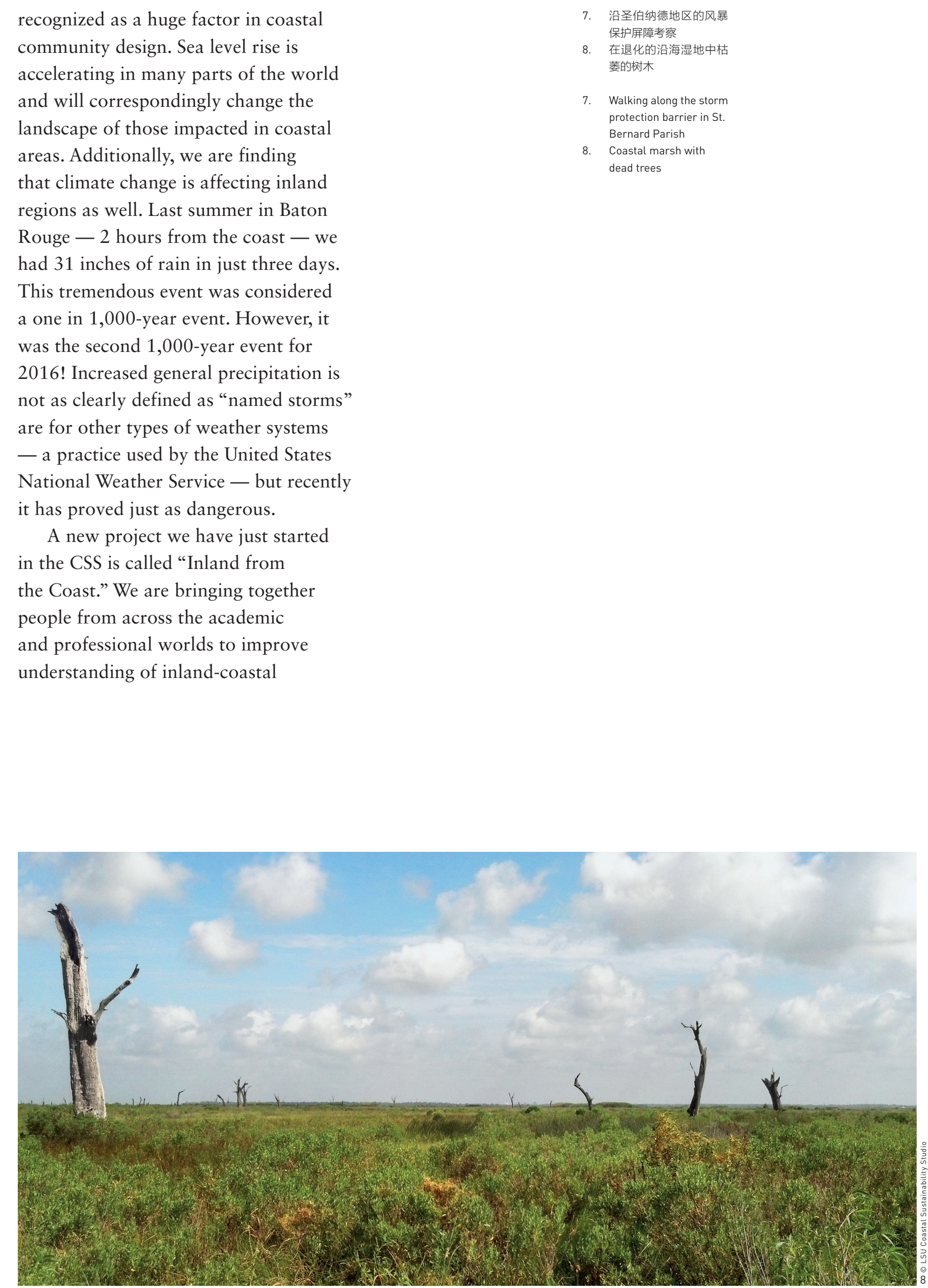
environmental conditions and vulnerabilities, determine indicators of community health and wellbeing, and develop best design and planning practices for reducing risk and increasing adaptive capacity. Research findings will be put into practice through local partnerships with professional architects, engineers, landscape architects, planners, policymakers, and community members. In particular, the project team is looking for the best ways to help the Greater Baton Rouge region — hit so hard by flooding - emerge more resilient from last year's devastating events. Additionally, the project's resulting framework will be applicable to communities across the Gulf Coast and beyond.

Human production and living has greatly intervened the coastal ecosystem. In CSS' practice, how to harmonize human activities with coastal ecosystem preservation? What role does public communication and education play in this aspect?

CARNEY: The landscape architect from the very beginning has had a role in telling the story - of putting the complexities of the ecosystem into a human context. Our field is responsible for people above all else. We do not "restore" ecosystems for their own sake but for the use, health, and enjoyment of people. Engineers and coastal scientists are taking note and acknowledging that their approach often leaves humans out of the picture. Consequently, the best restoration plans in the world often sit on the shelf because people simply do not understand or value them enough.

With regard to CSS's efforts in public communication and education, I would like to suggest the project of Center

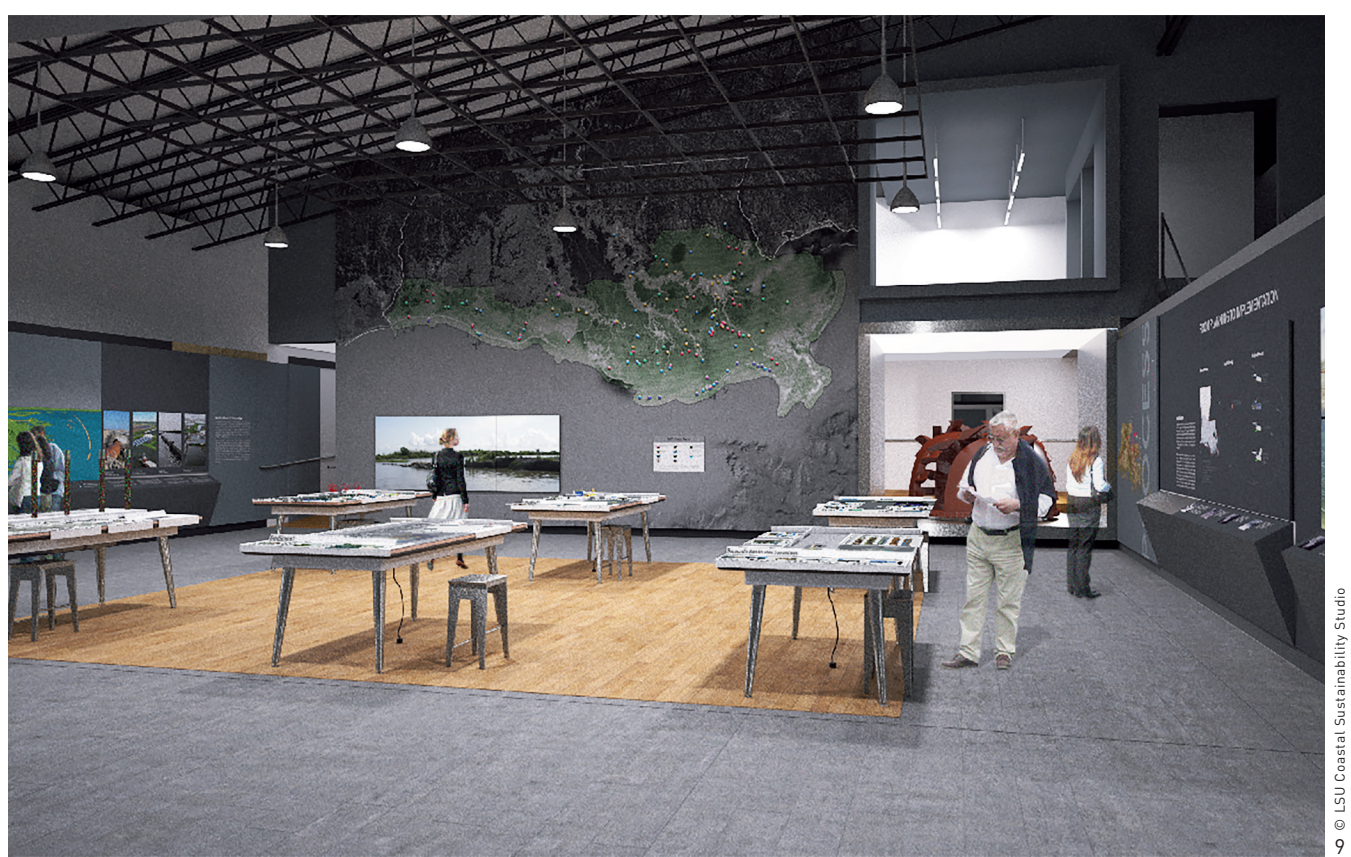

for River Studies (CRS) Exhibition Design. The CRS is the culmination of several years of work for the Coastal Protection and Restoration Authority (CPRA), a state governmental agency with authority to develop, articulate, and enforce a comprehensive restoration and protection plan developed to reduce hurricane storm surge flood hazards, restore Louisiana's bountiful natural resources, build land to protect our nation's critical energy infrastructure, and secure Louisiana's coast now and for future generations. Faced with the challenges of communicating the extremely complex science of coastal restoration and protection to the public, CPRA hired CSS to help craft the vision, narrative, and demonstration of projects through an exhibition entitled "Shifting Foundations" that is part of a large physical river model.

Scheduled to open in fall 2017, CRS is an incredible program not just for its scientific value as a research facility but for the effort to communicate complex

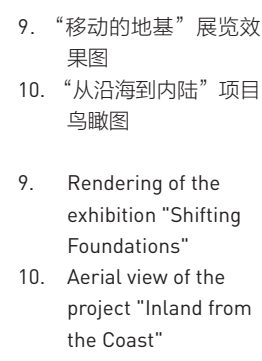
果图

10. “从沿海到内陆” 项目 鸟敗图

9. Rendering of the exhibition "Shifting Aerial view of project "Inland from
perial view of the the Coast" 
coastal and river research, restoration, and coastal protection efforts.

\section{We understand that CSS' practices} focus mainly on addressing the complex problems facing coastal Louisiana.

Do you believe that CSS' experiences

can also offer inspiring significance

responding to worldwide coastal issues?

CARNEY: Absolutely! First, I believe wholeheartedly that designers have much more agency in the world when they are skilled at collaborating with a large and diverse team of participants. That is why interdisciplinary pursuits are at the heart of almost everything CSS does. The challenges that we face in the Mississippi River Delta Plain represent a challenge currently facing many deltas around the world. Deltas are where roughly 500 million people live. These environments are mostly subsiding while sea levels are rising. These deltas, regardless of where they are located, share a similar reliance on natural resource extraction, have growing populations, and often disparate levels of wealth and poverty. Beyond deltas, coastal communities and inland areas are now seeing the results of the same forces that have affected the Mississippi River Delta for a generation. South Louisiana is the "canary in the coal mine" and Hurricane Sandy was a wakeup call to the world that this was not a threat limited to deltas. Coasts and their inland regions are at risk everywhere; so, designing and developing productive and responsible ways to live and work in these complex and dynamic environments must engage a wide range of knowledgeable participants - which is precisely what we try to do every day in the CSS. LAF

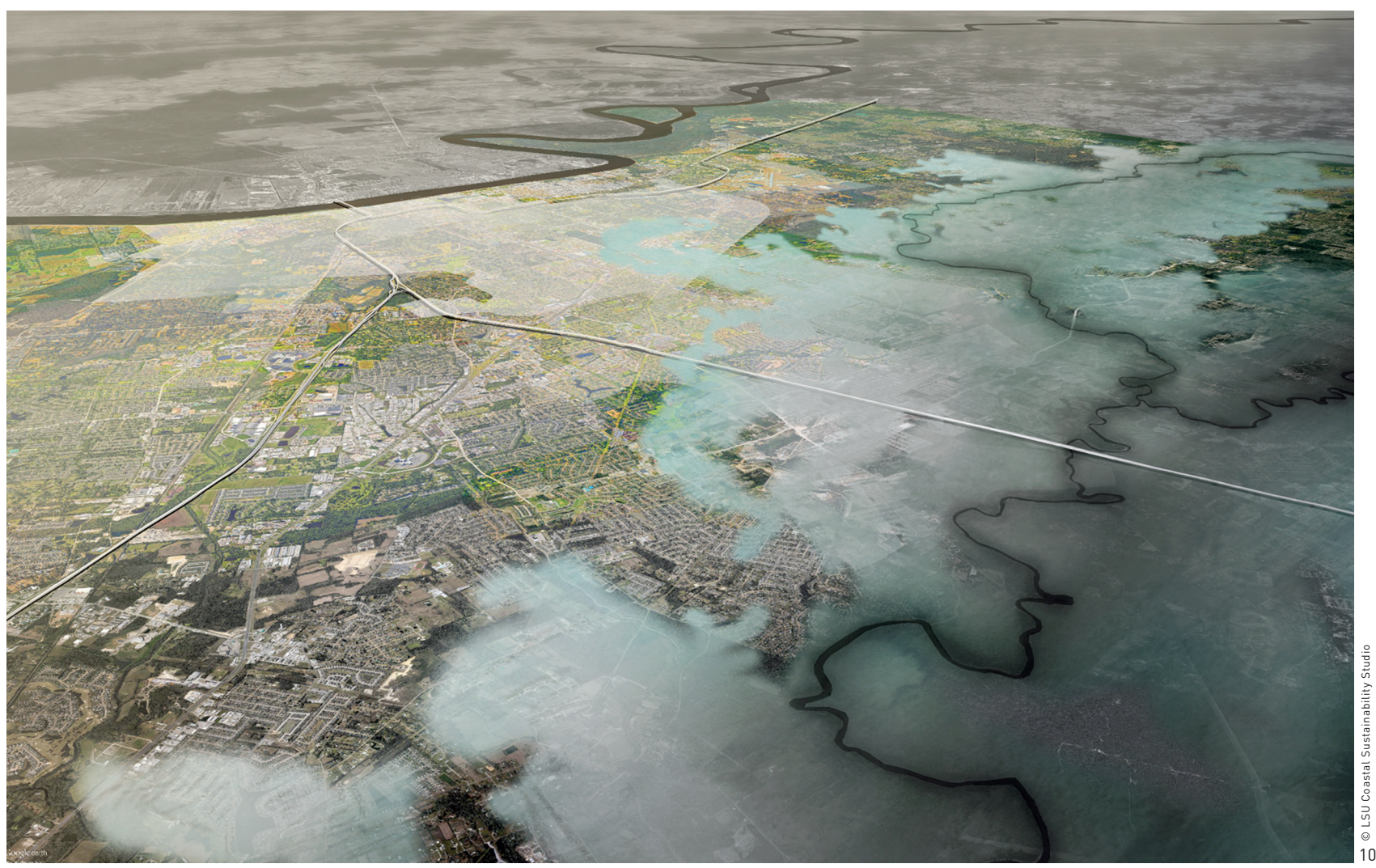

